\title{
COLOLEJEUNEA METZGERIOPSIS, A NEW SPECIES RECORD FOR THAILAND
}

\author{
J. Sangrattanaprasert ${ }^{1}$, S. Kornochaleart ${ }^{2}$ and S. Chantanaorrapint ${ }^{1 *}$ \\ ${ }^{1}$ Department of Biology, Faculty of Science, Prince of Songkla University \\ Hat Yai, Songkhla 90112, Thailand; E-mail: *sahut.c@psu.ac.th \\ ${ }^{2}$ Biological Science Program, Faculty of Science and Technology, Chiang Rai Rajabhat University \\ Chiang Rai 57100, Thailand; E-mail: kornochalert@gmail.com
}

(Received: 6 December, 2018; Accepted: 8 April, 2019)

Cololejeunea metzgeriopsis (K. I. Goebel) Gradst. et al., a neotenic liverwort, was newly discovered in lowland evergreen forest, southern Thailand. A description and illustrations of Thai plants are provided.

Key words: epiphyllous liverworts, Metzgeriopsis pusilla, neoteny, southern Thailand

\section{INTRODUCTION}

With more than 400 currently published species, Cololejeunea (Spurce) Steph. is considered the largest genus of Lejeuneaceae (Söderström et al. 2016, Yu et al. 2013). The genus is widely distributed in the humid tropics, subtropics and in some of the oceanic warm temperate area, and is mostly found on living leaves (Pócs and Piippo 2012). Thirteen subgenera are currently accepted in the genus, namely subg. Aphanolejeunea (A. Evans) Pócs, subg. Austrocololejeunea Tixier, subg. Chlorocolea R. M. Schust., subg. Chlorolejeunea Benedix, subg. Chondriolejeunea Benedix, subg. Cololejeunea, subg. Cryptolejeunea Benedix, subg. Diaphanae R. M. Schust., subg. Leptocolea (Spruce) Schiffn., subg. Metzgeriopsis (K. I. Goebel) Pócs, subg. Pedinolejeunea Benedix ex Mizut., subg. Protocolea R. M. Schust., and subg. Taeniolejeunea (Zwickel) Benedix (Pócs and Piippo 2012, Söderström et al. 2016).

In Thailand, Cololejeunea was first reported by Stephani (1902), who described C. schmidtii Steph. and C. siamensis Steph. from Koh Chang Islands. Later, more new Cololejeunea species and new distribution records from Thailand were published over the next one hundred years. So far, about 50 species have been reported for the country (Chantanaorrapint and Pócs 2014, He et al. 2012, Lai et al. 2008, Phetkhajone and Chantanaorrapint 2018, Pócs and Podani 2015). During botanical surveys in southern part of Thailand, Cololejeunea metzgeriopsis (K. I. Goebel) Gradst. et al. was discovered. 


\title{
TAXONOMIC TREATMENT
}

\author{
Cololejeunea metzgeriopsis (K. I. Goebel) Gradst. et al., Bot. J. Linn. Soc. \\ 151: 306 (2006)
}

(Fig. 1)

Basionym: Metzgeriopsis pusilla K. I. Goebel, Ann. Jard. Bot. Buitenzorg 7: 54 (1888). $\equiv$ Lejeunea metzgeriopsis K. I. Goebel, Flora 72: 2 (1889). - Type: lost. Neotype designated by Gradstein et al. (2006): Malaysia, Perak, Taiping, Bukit Larut ('Maxwell Hill'), 1,100-1,200 $\mathrm{m}$, humid secondary montane forest along road to summit, abundant on palm leaves, 8 March 2004, Gradstein, Ilkiu-Borges \& Yong 10435 (neotype: GOET; isoneotypes: CAS, G, JE, KTU, NY, UBC).

Plants pale-green, turning whitish green when dry, thallose, prostrate, unistratose, without costa; thallus irregularly pinnate or bipinnate, 300-440 $\mu \mathrm{m}$ wide (including cilia), main axis usually broader than branches; dorsal surface of thallus bearing finger-like rhizoidal outgrowth; thallus margins densely ciliate, 3-7 cells long. Thallus cells in apical portion of branches isodiametric to slightly rectangular, 14-24 × 12-18 $\mu \mathrm{m}$, thin-walled, intercellular space usually absent; in basal portion of branches and main axis rectangular to isodiametric, 30-50 × 16-26 $\mu \mathrm{m}$, thick-walled with trigone and 1-2 intermediate wall thickenings, the trigones and intermediate thickenings frequently with an intercellular space. Oil bodies not seen. Rhizoids hyaline or pale brown, frequently branched at the apex, arranged in 2 irregular rows on ventral surface of thallus. Asexual reproduction by discoid gemmae, occurring near the base of cilia.

Dioicous. Androecia in short spikes of 3-6 pairs of lobulate bracts, bract lobe rhombic, 380-400 × 160-200 $\mu \mathrm{m}$, apexes acuminate to acute, free margin crenulate; bract lobule oblong to hemispherical, 220-320 × 96-140 $\mu \mathrm{m}$, apexes acuminate to obtuse; antheridia 2 per bract; bracteoles absent; a tuft of rhizoids present at the base of the male spike. Gynoecia and sporophyte not seen on Thailand specimens.

Habitat and ecology: Cololejeunea metzgeriopsis was found on living leaves from high humid lowland to lower montane rain forests at altitude between ca 500 and $1,700 \mathrm{~m}$.

Distribution: Fiji Islands, Indonesia, Malaysia, New Caledonia, Papua New Guinea, Philippines (Gradstein et al. 2006, Pócs and Piippo 2012), new to Thailand.

Representative specimens examined: MALAYSIA. Pahang, Cameron Highlands, Gunung Batu Brinchang, 04 30' 24" N, 101 23' 13.9” E, 1,705 m, 15 February 2015, Sangrattanaprasert 263/15F, 266/15B, 278/15D (PSU); Fraser's Hill, 03 42' 56.0" N, 10144'11.4" E, 1,230-1,277 m, 8-11 April 2014, Sangrattanaprasert 59/14C (PSU). - THAILAND. Hat Yai, 


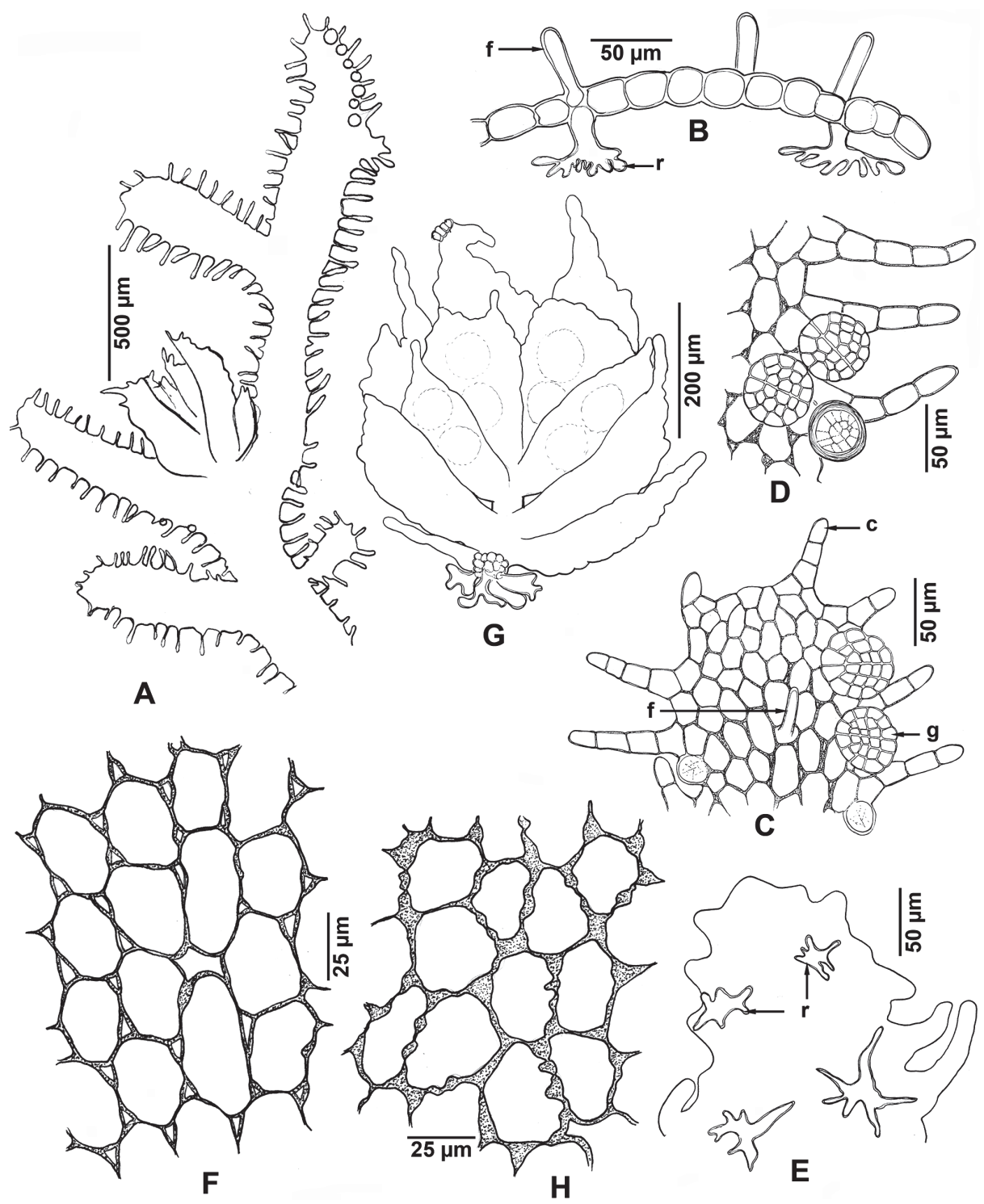

Fig. 1. Cololejeunea metzgeriopsis (K. I. Goebel) Gradstein et al. $-\mathrm{A}=$ male thallus with androecium, dorsal view; $B$ = cross section of thallus, showing finger-like outgrowth (f) and rhizoids (r); $\mathrm{C}=$ apical portion of thallus in dorsal view, showing finger-like outgrowth, discoid gemmae (g) and cilia (c); D = thallus margins, showing gemmae and cilia; $\mathrm{E}=$ thallus in ventral view showing rhizoids; $\mathrm{F}=$ cells of main axis of thallus, showing thickenings with intercellular spaces; $\mathrm{G}=$ androecium, ventral view; $\mathrm{H}=$ cells of male bract, showing trigones and intermediate thickenings without intercellular spaces. All from Chantanaorrapint \& Promma 2549D (PSU) 
Ton Nga Chang Wildlife Sanctuary, Ton Nga Chang Waterfall, $06^{\circ} 56^{\prime} 43.91^{\prime \prime}$ N, $100^{\circ} 13^{\prime}$ 16.43" E, 495-500 m, 11 January 2014, Sangrattanaprasert 51/14C (PSU); 4 Oct. 2014, Sangrattanaprasert 206/14B (PSU). Yala, Betong, Ban Chulabhorn Pattana 10, 05 49'04.40" N, $101^{\circ} 01^{\prime} 50.20^{\prime \prime}$ E, 570 m, 15 June 2013, Chantanaorrapint and Promma 2549D (PSU).

Notes: Cololejeunea metzgeriopsis is easily separated from other Cololejeunea species by its thalloid habit consisting of unistratose thallus and having leafy branches only in the form of male and female gametangia on thallus margins. Cololejeunea metzgeriopsis might be confused with the members of the genus Metzgeria Raddi in general appearance. However, the latter differs from C. metzgeriopsis in having multistratose costa.

Acknowledgements - The authors would like to thank J. Sae Wai, C. Promma, P. Rojchanaumpawan, N. Putthisawong, and O. Suwanmala for their help during the fieldwork; and Prof. Dr T. Pócs and Dr S. K. Singh for their useful suggestions. This work was supported by Prince of Songkla University annual government of expenditure under Plant Genetic Conservation Project under the Royal initiative of Her Royal Highness Princess Maha Chakri Sirindhorn year 2019 (no. SCI600107S).

\section{REFERENCES}

Chantanaorrapint, S. and Pócs, T. (2014): Southern Thailand bryophytes I, with description of Cololejeunea ramromensis. - In: Telnov, D. (ed.): Biodiversity, biogeography and nature conservation in Wallacea and New Guinea. The Entomological Society of Latvia, Riga, Vol. 2, pp. 113-122.

Gradstein, S. R., Wilson, R., Ilkiu-Borges, A. L. and Heinrichs, J. (2006): Phylogenetic relationships and neotenic evolution of Metzgeriopsis (Lejeuneaceae) based on chloroplast DNA sequences and morphology. - Bot. J. Linn. Soc. 151: 293-308. https://doi. org/10.1111/j.1095-8339.2006.00531.x

He, Q., Zhu, R.-L., Chantanaorrapint, S., Kornochalert, S. and Printarakul, N. (2012): Drepanolejeunea laciniata (Lejeuneaceae), a new species from northern Thailand. Cryptogamie, Bryol. 33: 291-298. https://doi.org/10.7872/cryb.v33.iss3.2012.291

Lai, M.-J., Zhu, R.-L. and Chantanaorrapint, S. (2008): Liverworts and hornworts of Thailand: an updated checklist and bryofloristic accounts. - Ann. Bot. Fennici 45: 321-341. https://doi.org/10.5735/085.045.0501

Phetkhajone, S. and Chantanaorrapint, S. (2018): Bryophytes at Khao Chian, Sadao district, Songkhla province. - Thai J. Bot. 10: 47-61.

Pócs, T. and Piippo, S. (2012): Bryophyte flora of the Huon Peninsula, Papua New Guinea. LXXIV. Cololejeunea (Lejeuneacea, Hepatice). - Acta Bryolich. Asiatica 4: 59-135.

Pócs, T. and Podani, J. (2015): Southern Thailand bryophytes II. Epiphylls from the PhangNga area. - Acta Bot. Hung. 57: 183-198. https://doi.org/10.1556/ABot.57.2015.1-2.14

Söderström, L., Hagborg, A., Von Konrat, M., Bartholomew-Began, S., Bell, D., Briscoe, L., Brown, E., Cargill, D. C., Costa, D. P., Crandall-Stotler, B. J., Cooper, E. D., Dauphin, G., Engel, J. J., Feldberg, K., Glenny, D., Gradstein, S. R., He, X., Heinrichs, 
J., Hentschel, J., Ilkiu-Borges, A. L., Katagiri, T., Konstantinova, N. A., Larraín, J., Long, D. G., Nebel, M., Pócs, T., Puche, F., Reiner-Drehwald, E., Renner, M. A. M., Sass-Gyarmati, A., Schäfer-Verwimp, A., Segarra Moragues, J. G., Stotler, R. E., Sukkharak, P., Thiers, B. M., Uribe, J., Váňa, J., Villarreal, J. C., Wigginton, M., Zhang, L. and Zhu, R.-L. (2016): World checklist of hornworts and liverworts. - PhytoKeys 59: 1-828. https://doi.org/10.3897/phytokeys.59.6261

Stephani, F. (1902): Hepaticae. In: Schmidt, J. (ed.), Flora of Koh Chang, part V. - Bot. Tidsskrift 24: 277-280.

Yu, Y., Pócs, T., Schäfer-Verwimp, A., Heinrichs, J., Zhu, R.-L. and Schneider, H. (2013): Evidence for rampant homoplasy in the phylogeny of the epiphyllous liverwort genus Cololejeunea (Lejeuneaceae). - Syst. Bot. 38: 553-563. https://doi. org/10.1600/036364413X670304 
